\title{
Domestic violence against women amidst the pandemic: coping strategies disseminated by digital media
}

\author{
Violência doméstica contra a mulher na pandemia: estratégias de enfrentamento divulgadas pelas mídias digitais
}

Violencia doméstica contra las mujeres en la pandemia: estrategias de afrontamiento difundidas por los medios digitales

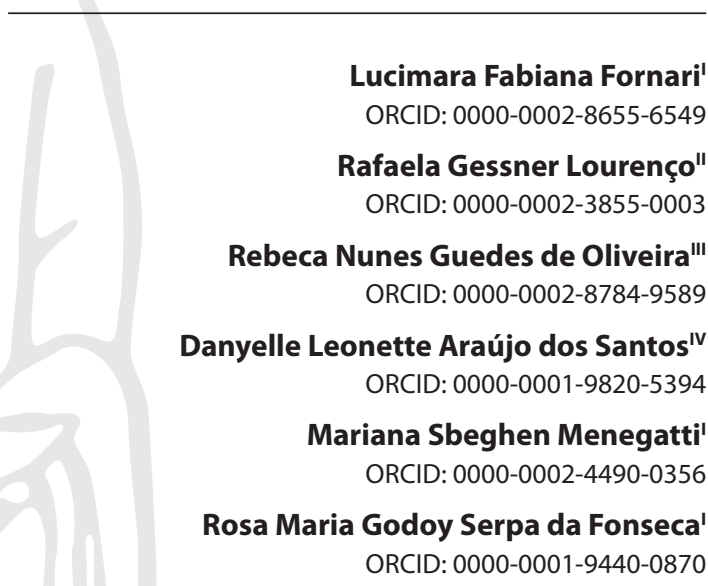

'Universidade de São Paulo. São Paulo, São Paulo, Brazil. "Universidade Federal do Paraná. Curitiba, Paraná, Brazil.

I' Universidade Municipal de São Caetano no Sul.

São Caetano do Sul, São Paulo, Brazil. "Secretaria Estadual de Saúde Pública do Rio Grande do Norte. Natal, Rio Grande do Norte, Brazil.

How to cite this article: Fornari LF, Lourenço RG, Oliveira RNG, Santos DLA Menegatti MS, Fonseca RMGS. Domestic violence against women amidst the pandemic: coping strategies disseminated by digital media.

Rev Bras Enferm. 2021;74(Suppl 1):e20200631. doi: http://dx.doi.org/10.1590/0034-7167-2020-0631

Corresponding author:

Lucimara Fabiana Fornari

E-mail: lucimarafornari@usp.br

EDITOR IN CHIEF: Dulce Barbosa ASSOCIATE EDITOR: Ana Fátima Fernandes

\section{ABSTRACT}

Objective: to know the strategies to cope with domestic violence against women disseminated by digital media at the beginning of the COVID-19 pandemic. Methods: a documentary study with a qualitative approach. The search took place from March 11 to April 30, 2020, from four sources: newspapers and online portals, social network, official government pages and third sector portals. Thematic content analysis of the findings was performed. Results: seventy-seven strategies were identified in the journalistic press, 93 in the social network, 45 in government portals and 40 in third sector organizations. From analysis, three empirical categories emerged: Strategies for communication with women; Strategies adopted by customer service; Strategies to inform the population. Final considerations: most of strategies were adaptations of existing services, centered on the reporting of violence by women. Descriptors: Domestic Violence; Violence Against Women; Pandemics; National Strategies; Communications Media.

\section{RESUMO}

Objetivo: conhecer as estratégias de enfrentamento da violência doméstica contra a mulher divulgadas pelas mídias digitais no início da pandemia de COVID-19. Métodos: estudo documental de abordagem qualitativa. A busca aconteceu de 11 de março a 30 de abril de 2020, em quatro fontes: jornais e portais online, rede social, páginas oficiais governamentais e portais do terceiro setor. Realizou-se análise de conteúdo temática dos achados. Resultados: foram identificadas 77 estratégias na imprensa jornalística, 93 na rede social, 45 nos portais governamentais e 40 nas organizações do terceiro setor. Da análise, emergiram três categorias empíricas: Estratégias para comunicação com as mulheres; Estratégias adotadas pelos serviços de atendimento; Estratégias para informar a população. Considerações finais: a maior parte das estratégias foram adaptações de serviços já existentes, centradas na denúncia da violência pelas mulheres.

Descritores: Violência Doméstica; Violência contra a Mulher; Pandemias; Estratégias Nacionais; Meios de Comunicação.

\section{RESUMEN}

Objetivo: conocer las estrategias para enfrentar la violencia doméstica contra las mujeres difundidas por los medios digitales al inicio de la pandemia de COVID-19. Métodos: estudio documental con enfoque cualitativo. La búsqueda se realizó del 11 de marzo al 30 de abril de 2020, a partir de cuatro fuentes: periódicos y portales en línea, red social, páginas oficiales del gobierno y portales del tercer sector. Se realizó un análisis de contenido temático de los hallazgos. Resultados: se identificaron 77 estrategias en la prensa periodística, 93 en la red social, 45 en portales gubernamentales y 40 en organizaciones del tercer sector. Del análisis surgieron tres categorías empíricas: Estrategias de comunicación con las mujeres; Estrategias adoptadas por el servicio al cliente; Estrategias para informar a la población. Consideraciones finales: la mayoría de las estrategias fueron adaptaciones de servicios existentes, centradas en la denuncia de violencia por parte de mujeres.

Descriptores: Violencia Doméstica; Violencia contra la Mujer; Pandemias; Estrategias Nacionales; Medios de Comunicación. 


\section{INTRODUCTION}

Social distancing, aiming to contain the community transmission of SARS-CoV-2, with the closing of schools, commerce, companies and other non-essential services, restricted people to their homes and raised a public health problem that was already before the pandemic, domestic violence against women ${ }^{(1)}$. This situation has caused increased concern about these cases, as highlighted by the United Nations - Women ${ }^{(2)}$.

It was found that in countries like China, the United Kingdom and the United States of America there was an increase in cases of domestic violence against women, since the beginning of the COVID-19 pandemic ${ }^{(1)}$.

In Brazil, the numbers indicate a similar scenario, with a significant increase in some states of the federation, when compared to March and April 2019. Complaints to Call 180 - telephone number to report violence against women - increased $17.9 \%$ in March and $37.6 \%$ in April 2020, and femicides grew 22\% in 12 states ${ }^{(3)}$.

Research indicates that the domestic space is a privileged locus of violence against women ${ }^{(4-5)}$. If this were the previous reality, during the pandemic, the problem was aggravated. The confinement led to an exponential increase in coexistence, expanding the possibilities of tensioning interpersonal relationships and intensifying family stress, including that of women with their offenders. Situations such as economic instability and unemployment have also reinforced the economic dependence of women and have started to threaten the status of the culturally constructed man as a provider more, which may result in intrafamily violence as a mechanism to reaffirm male power( ${ }^{(6)}$.

In addition to these, several other elements contributed to hamper family relationships, also with very unfavorable consequences for women's lives. As the number of people and the time spent at home increased, the workload of women increased due to the accumulation of household chores and childcare, elderly and sick people. Home office work is often superimposed on this for both men and women, turning the home into a place of production and social reproduction, without adequate conditions for this. Surrounding the private space also limited the relationship of women with their social support network, such as family, community, work and social facilities in the territory, as well as minimizing the possibilities of identifying and addressing the problem of violence ${ }^{(7)}$.

Due to social isolation, access to support services for women in situations of violence, specialized and non-specialized, was also hampered. This contributed to the continuity and worsening of previous situations of violence, as well as to the violations that started to occur in the pandemic, referring to the need to adopt or reinforce strategies to cope with the problem ${ }^{(2-7)}$.

Given the above, it can be said that the pandemic has increased the vulnerability of women to domestic violence, a phenomenon historically constructed and chronic, with serious physical, emotional and social consequences for the whole family. Much more than the product of a relationship between cause and effect, it is determined by gender constructions that underlie social relations between men and women, men and men, and women and women ${ }^{(8-9)}$.

The worsening of the phenomenon generated the need for multiplication of coping strategies by society, including actions that would be within the reach of women, transmitted through digital media, which also began to expand their social function of informing the population during the pandemic.

This study is relevant, as it compiles and analyzes strategies that were developed with a view to containing domestic violence against women and its results reflect a favorable historical moment to shed light on a naturalized and invisible problem in many aspects. Therefore, it is believed that they can subsidize the development of new strategies that better respond to violence against women ${ }^{(10)}$, especially during the COVID-19 pandemic.

\section{OBJECTIVE}

To know the strategies to cope with domestic violence against women disseminated by digital media at the beginning of the COVID-19 pandemic.

\section{METHODS}

\section{Ethical aspects}

This study did not need a Research Ethics Committee appreciation, as it used news and comments made available publicly and with free access to information on the investigated sites of the news portals, newspapers, government pages, third sector services and the social network.

\section{Theoretical-methodological framework}

This study used as a theoretical-methodological framework the category of gender violence, anchored in historical and dialectical materialism ${ }^{(11)}$.

\section{Type of study}

This is a documentary study with a qualitative approach, which investigated news and comments that dealt with domestic violence perpetrated against women during the COVID-19 pandemic. The Consolidated criteria for reporting qualitative research (COREQ) instrument was used to guide methodological procedures.

\section{Study setting and data source}

Four sources comprised the corpus of analysis: a) news published on two Brazilian virtual portals (P1 and P2) and the digital version of two national newspapers (N1 and N2); b) comments published on the social network Twitter (T1-499); c) information published on the official pages of the Federal Government, the Federal District and the 26 Brazilian states (identified by the acronym of the state they represent); d) four Brazilian portals linked to the third sector (TS1, TS2, TS3, and TS4).

The four types of data sources were selected due to the important role of digital media in the transmission of information in the Brazilian territory, as well as for the construction of public opinion on the subject. Additionally it should be noted that the set of sources is justified by the representation of communication channels from the three sectors of civil society (government, private companies and non-profit institutions). 


\section{Data collection and organization}

Data collection took place from March 11 to April 30, 2020. The starting period of the search was chosen by the date on which the World Health Organization (WHO) decreed the world pandemic of COVID-19 ${ }^{(12)}$. News and comments addressing violence against women at the beginning of the social isolation adopted to contain the COVID-19 pandemic were included and exclusion criteria were not defined.

The search strategy was carried out on each of the investigated sites using a specific search field for the pages visited. The following search strategies were used: "violence against women" AND ("covid-19" OR "coronavirus" OR "pandemic" OR "isolation"). With the exception of government portals, as the search was carried out only with the word "violence".

Data extraction was performed using a semi-structured instrument built to capture the following information: date of publication; publication time; country of publication; language; authorship; information vehicle; source of information; strategies for coping with violence against women.

\section{Data analysis}

The excerpts of the selected news and comments were subjected to thematic content analysis, consisting of pre-analysis, material exploration, treatment of results, interpretation and inference ${ }^{(13)}$. Analysis for the understanding of the research object was carried out from the analytical category "gender violence".

\section{RESULTS}

In the journalistic press, 150 news items were selected from virtual portals and newspapers with online edition. Most were published by Portal $1(n=66)$, followed by Portal $2(n=55)$. The researched newspapers published 18 (N1) and 11 (N2) news, respectively. Most authors were female $(n=68)$, followed by male $(n=10)$ and two stories had shared authorship. Authorship was not reported in 70 reports. With regard to content, in 97 news items, 77 strategies were identified with different content and implementation contexts.

On Twitter, 499 comments were selected. Most $(n=307)$ were published by users, 192 of whom were female and 115 were male. The rest was published by the press $(n=70)$, by non-governmental organizations ( $n=41)$, government agencies $(n=33)$, personal blogs $(n=28)$, companies $(n=9)$, political parties $(n=6)$, and universities $(n=5)$. As for the content of the tweets, 326 were comments on the topic, 68 were news shares, nine podcasts, three free online courses, and 93 dealt with strategies to cope with violence against women.

In the government portals, 45 publications were selected. Among the Brazilian states, eight did not publish any information on the subject: Mato Grosso (MT), Minas Gerais (MG), Maranhão (MA), Rio Grande do Norte (RN), Rio Grande do Sul (RS), Roraima (RR), Rondônia (RO) and Tocantins (TO). Authorship was reported from nine sources, seven from female authors and two from men. All selected publications dealt with coping strategies implemented in the states of the federation and in the Federal District.
In the four portals of third sector organizations (TS), 42 publications were selected, the largest number of them originally published in various news portals and shared by TS1 $(n=37)$ and TS2 $(n=1)$, while the TS3 portals $(n=2)$ and TS4 $(n=2)$ published opinion articles by registered authors. As for authorship, 18 publications did not inform the author's gender, 18 were published by women, three by men and three had shared authorship. Concerning the strategies disclosed, 40 publications mentioned a strategy to cope with violence against women, with 29 different strategies implemented in Brazil being highlighted.

Considering the start date of the world pandemic Decree and its subsequent 40 days, there was a growing increase in the number of publications published in each data source, mainly on Twitter and news portals (Figure 1).

Sources updated in the period

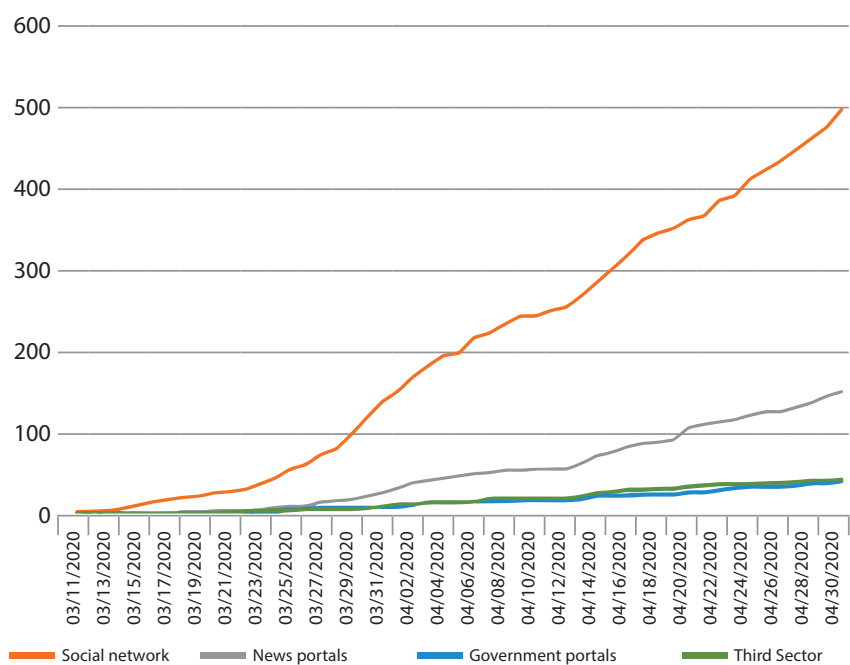

Figure 1 - Publications published on digital media from March 11 to April 20, 2020

From analysis of the content of the news and comments, three empirical categories emerged: strategies for communicating with women, strategies adopted by care services, and strategies to inform the population.

\section{Strategies for communicating with women}

Among the measures taken to prevent the COVID-19 pandemic from spreading, social isolation was the main recommendation. Thus, there was guidance for the population to remain restricted to the domestic space, usually a privileged setting for various problems, including violence against women.

The four data sources disclosed channels for reporting through a telephone line or the internet (Chart 1). With regard to the telephone route, toll-free numbers and smartphone applications were shared, which also had the functionality of monitoring the emergency protective measures used by the victims.

In relation to the internet, electronic pages and two digital robots were disseminated that provided information on procedures for reporting violence. In addition to information for women, electronic services were identified that sought to map cases of violence and specialized services to deal with the problem. 
Chart 1 - Channels for reporting via telephone line or internet

\begin{tabular}{|c|c|c|c|}
\hline Strategy & Description & Place & Data source \\
\hline \multirow{4}{*}{$\begin{array}{l}\text { Telephone } \\
\text { channels for } \\
\text { complaints }\end{array}$} & Call 180, 100, 181, 197, 129, 190 and 192 & National & $\begin{array}{l}\text { Press (N1, N2, P1, P2), Twitter, Government } \\
\text { (Federal, AC, AL, BA, PR, SC, PB, PE, GO, PI, SP), } \\
\text { TS1, TS3 }\end{array}$ \\
\hline & $\begin{array}{l}\text { Telephone 0800: State Ombudsman for Women, State Ombudsman for } \\
\text { Human Rights and Maria da Penha Patrol (Patrulha Maria da Penha) }\end{array}$ & $P E, B A, R J$ & Press (P1), Government (PE, BA, RJ), TS1 \\
\hline & $\begin{array}{l}\text { Cell phone:Women's Department, Domestic Violence Court, Public } \\
\text { Prosecutor's Office, Domestic Violence Unit of the Public Defender's Office }\end{array}$ & $\mathrm{PE}, \mathrm{AP}$ & Press (P1), Twitter, Government (AP), TS1, TS3 \\
\hline & Specific telephone service channel & $A C, P I, S P, A M$ & Press (P1), Government (PI, SP) \\
\hline \multirow{7}{*}{ Applications } & WhatsApp: Women's Protection Service, Civil Police, Public Defender & $\begin{array}{l}\mathrm{SC}, \mathrm{RS}, \mathrm{AC}, \mathrm{AL}, \\
\mathrm{AP}, \mathrm{FD}, \mathrm{PI}, \mathrm{GO}\end{array}$ & $\begin{array}{l}\text { Press (P1, P2, N2), Twitter, Government (AC, } \\
\text { AL, AP, FD, PA, PB, PI, SC, GO), TS1, TS3 }\end{array}$ \\
\hline & SOS Women: protective measure, emergency service, location and help & National & Press (N2, P2), Twitter, TS1 \\
\hline & Button of Life (Botão da Vida): protective measure & $A C$ & Government (AC) \\
\hline & BR Human Rights: complaint & National & Press (P2), Twitter, Government (Federal), TS1 \\
\hline & MG Women: guidance and information & MG & Press $(\mathrm{P} 1)$ \\
\hline & Save Maria (Salve Maria): report and location & $\mathrm{PI}$ & Press (P1), Twitter \\
\hline & Goiás Safety: report & GO & Government (GO) \\
\hline \multirow{3}{*}{ Home page } & Ombudsman of the Ministry of Women, Family and Human Rights & National & $\begin{array}{l}\text { Press (P2), Twitter, Government (Federal, BA), } \\
\text { TS1, TS3 }\end{array}$ \\
\hline & "Women's Letter" ("Carta de Mulheres") Project & SP, PE & Press (N2, P1) \\
\hline & "Don't be silent" ("Não se Cala") project & MT & Government (MT) \\
\hline \multirow{2}{*}{$\begin{array}{l}\text { Artificial } \\
\text { intelligence }\end{array}$} & Isabot: information and reception & National & Twitter, Press (P2), TS1 \\
\hline & lara: information and complaint & PA & Government (PA) \\
\hline \multirow[b]{2}{*}{ Mapping } & Data collection: Iris System, Domestic Violence Monitor against Women & National, RJ & Press (P2), Twitter, TS1 \\
\hline & $\begin{array}{l}\text { Map of services: I'mWithThem (TôComElas), WeAreTogether } \\
\text { (NósEstamosJuntas) }\end{array}$ & National & Twitter \\
\hline
\end{tabular}

\section{Strategies adopted by customer service}

The four data sources addressed measures adopted by specialized and non-specialized services to assist women in situations of violence (Chart 2). The services responsible for psychological, police and legal services have adopted the extension of in-person service hours and the possibility of remote service, by telephone or internet.

In Minas Gerais (MG), the services that make up the judicial system maintained remote calls. In Bahia (BA), emergency protective measures for women in situations of violence were extended, implemented in the period before the pandemic and which were in progress during the period of social isolation.
With regard to the legislative system, in view of the increase in the number of situations of domestic violence against women, work groups were created to build a contingency plan and draft laws. Three laws were enacted in the Federal District to combat violence against women. The first law states that commercial establishments (bars, restaurants, and nightclubs) need to assist women who feel at risk ${ }^{(14)}$. The second law establishes that drivers and collectors must report cases of sexual violence and harassment in public transport ${ }^{(15)}$. The third law requires residential condominiums to report the occurrence or evidence of domestic and family violence against resident women, children, adolescents or elderly people ${ }^{(16)}$.

Chart 2 - Strategies for services that address violence against women

\begin{tabular}{|l|l|c|l|}
\hline Strategy & Description & Place & Data source \\
\hline \multirow{5}{*}{$\begin{array}{l}\text { Shelter } \\
\text { services }\end{array}$} & Brazilian Women's House (Casa da Mulher Brasileira): service & National & Press (P1, P2, N2) \\
\cline { 2 - 4 } & $\begin{array}{l}\text { Specialized Reference Center for Assistance to Women Victims of Violence: } \\
\text { on call, special hours }\end{array}$ & RO, SP, BA, RJ & Press (P1, N2), Twitter, TS1 \\
\cline { 2 - 4 } & NGO Start Over (ONG Recomeçar): shelter & SP & Press (P2) \\
\cline { 2 - 4 } & Domestic Violence Prevention Assistance: care & FD & Twitter \\
\cline { 2 - 4 } & Shelter Houses: care & FD, ES, PB, PE, RJ & Government (FD, ES, PB, PE, RJ) \\
\hline \multirow{3}{*}{$\begin{array}{l}\text { Psychological } \\
\text { support }\end{array}$} & $\begin{array}{l}\text { Virtual: Women's Police Station, Women's Service Center, State Department for } \\
\text { Social Assistance, Human Rights and policies for Women }\end{array}$ & MT, AL, AC, MG & $\begin{array}{l}\text { Press (P1), Government (AL), } \\
\text { Twitter, TS1, TS4 }\end{array}$ \\
\cline { 2 - 4 } & Telephone: Reference and Victim Support Center & SP & Government (SP) \\
\hline
\end{tabular}


Chart 2 (concluded)

\begin{tabular}{|c|c|c|c|}
\hline Strategy & Description & Place & Data source \\
\hline $\begin{array}{l}\text { Maria da } \\
\text { Penha Patrol }\end{array}$ & Maintains in-service in the rounds, Remote service, by phone and 24 hours & $\begin{array}{l}\mathrm{SP}, \mathrm{RS}, \mathrm{BA}, \mathrm{Pl}, \mathrm{PR} \\
\mathrm{AC}, \mathrm{AL}\end{array}$ & $\begin{array}{l}\text { Press (P1, P2), Twitter, } \\
\text { Government (AC, AL), TS1, TS4 }\end{array}$ \\
\hline \multirow{3}{*}{$\begin{array}{l}\text { Civil police } \\
\text { station }\end{array}$} & Online registration of reports and crimes & SC, SP, ES, SE & $\begin{array}{l}\text { Press (P1, P2), Government (SE), } \\
\text { TS1, TS4 }\end{array}$ \\
\hline & Online police report & $\begin{array}{l}\text { SP, AP, CE, FD, GO, } \\
\text { MT, PB, PE, PI, PR, } \\
\text { SC, SE }\end{array}$ & $\begin{array}{l}\text { Press (P1, P2), Twitter, } \\
\text { Government (AP, CE, FD, GO, } \\
\text { MT, PB, PE, PI, PR, SP, SC, SE), } \\
\text { TS1, TS3, TS4 }\end{array}$ \\
\hline & Request for emergency protective measures online & PB, FD, PR & $\begin{array}{l}\text { Press (P1), Twitter, Government } \\
\text { (PB), TS1, TS3, TS4 }\end{array}$ \\
\hline \multirow{2}{*}{$\begin{array}{l}\text { Justice } \\
\text { system }\end{array}$} & Extension of protective measures for women victims & BA & $\begin{array}{l}\text { Press (P1), Government (BA), } \\
\text { TS1 }\end{array}$ \\
\hline & Remote service: Court of Justice of Minas Gerais & MG & Press (P1) \\
\hline \multirow{5}{*}{$\begin{array}{l}\text { Legislative } \\
\text { system }\end{array}$} & $\begin{array}{l}\text { Contingency Plan for the prevention and repression of domestic violence } \\
\text { and against women during the pandemic }\end{array}$ & National, PB & $\begin{array}{l}\text { Press (P1), Government } \\
\text { (Federal) }\end{array}$ \\
\hline & $\begin{array}{l}\text { Draft Law: expanding the dissemination of Call 180, adopting measures to } \\
\text { cope with violence }\end{array}$ & $\begin{array}{l}\text { National, MT, RJ, AM, } \\
\text { SP, BA }\end{array}$ & Press (P2), Twitter, TS1, TS4 \\
\hline & $\begin{array}{l}\text { Laws approved for condominiums, public transportation, bars, restaurants, } \\
\text { and nightclubs }\end{array}$ & FD & Press (P1), TS1 \\
\hline & Domestic Council of Justice: discussion of measures & National & Press (P2), Twitter \\
\hline & Coronavirus Coping Commission: discussion of measures & RN & Twitter \\
\hline
\end{tabular}

\section{Strategies to inform the population}

Information related to coping with domestic violence in the COVID-19 pandemic was disseminated mainly through booklets and virtual campaigns. Lives were also made by the Ministry of Women, Family and Human Rights of the Federal Government and by non-governmental organizations linked to the theme. Most of the lives were related to reflections on violence against women amidst the pandemic, to possible actions and measures to cope with the problem and to the service network.

Another strategy adopted was to encourage participation and guide neighbors to report cases. At the national level, there was a campaign for the violations that occurred inside the residences to be communicated to the public security organs by the liquidator or by the condominium administration. This measure highlights the importance of the informal support network in social isolation.

Two support groups for women in situations of violence were also identified through a messaging application, via smartphone. The first serves immigrant women from the east side of the municipality of São Paulo, receiving help requests and offering help. The second operates on the national scene and counts with 700 volunteers from law, psychology and social assistance, sheltering and guiding women who want to report their offenders. Other strategies are described in Chart 3.

The three empirical categories involved exclusively strategies presented at the state and federal levels. However, the news carried by the journalistic press and the third sector also addressed strategies developed internationally. In the newspapers, 15 international strategies were selected, 10 from European countries, four from Latin America and one from South Africa. The most popular was the presentation of alternative locations (pharmacies and supermarkets) so that women could request help when in situations of violence $(n=13)$. The alert system in pharmacies and supermarkets also appeared in publications in the third sector, highlighting experiences from France and Italy. France innovated by implementing strategies such as paying for hotel rooms and opening counseling centers to shelter victims. It draws attention to a strategy aimed at violent men with the aim of enabling listening via the telephone channel, so that they could communicate when in the process of committing an aggression. In Spain, a reporting channel was set up via the conversation app for women to send distress calls by text message to the police, to be found by geolocation.

Chart 3 - List of strategies adopted to inform the population

\begin{tabular}{|l|l|l|l|}
\hline Strategy & Description & Place & Data source \\
\hline Booklets & $\begin{array}{l}\text { Themes: isolation, violence at home, women's rights, guidelines, } \\
\text { recommendations and reporting }\end{array}$ & $\begin{array}{l}\text { National, RS, AP, } \\
\text { SP, AM, AC }\end{array}$ & $\begin{array}{l}\text { Press (P1, P2), Twitter, Government } \\
\text { (Federal, AP, AC) }\end{array}$ \\
\hline Campaigns & $\begin{array}{l}\text { Themes: reliquary, diary, isolation, domestic violence, stay at home, } \\
\text { May for of women's lives, you are not alone, combating violence } \\
\text { against women during the pandemic }\end{array}$ & $\begin{array}{c}\text { National, PE, SP, } \\
\text { FD, GO }\end{array}$ & $\begin{array}{l}\text { Press (N1, P1, P2), Twitter, Government } \\
\text { (FD, GO) }\end{array}$ \\
\hline Lives & $\begin{array}{l}\text { Themes: coping actions and measures, care modalities, support } \\
\text { network, violence against women, the role of psychology in coping } \\
\text { with violence, pandemic, social isolation, crisis context }\end{array}$ & National & Government (Federal, SP), Twitter \\
\hline
\end{tabular}




\begin{tabular}{|c|c|c|c|}
\hline Strategy & Description & Place & Data source \\
\hline \multirow{8}{*}{ Other actions } & Condominium participation in the complaint & National, FD & Press (P1, P2), Twitter, TS1 \\
\hline & Participation of neighbors in the complaint & National & Press (P2, N1), Twitter, Government (Federal) \\
\hline & Support group: immigrant women, Rede Justiceiras (Avengers Network) & SP & Press (P1, P2), TS1, TS2, TS3, TS4 \\
\hline & "Nós por Elas" ("We for Them") project: guidance for self-defense & SP & Press (N1) \\
\hline & Free transportation: Uber, 99 Taxis. & National & Press (P2), Twitter, TS1 \\
\hline & University: extension project, virtual assistance, online course & National, RN, PR & Twitter \\
\hline & Sentinel of Good: voluntary reception at police stations & National & Twitter \\
\hline & Solidary donation program for shelters & ES & Government (ES) \\
\hline
\end{tabular}

\section{DISCUSSION}

Violence against women is a structural phenomenon of society, determined by gender inequalities, which operate producing vulnerabilities in women's lives. Recognized since 2002 as a health problem with epidemic dimensions on the world stage ${ }^{(17)}$, it can be said that the "pandemic of gender violence" adds to the pandemic of COVID-19. Thus, vulnerabilities are enhanced for the health-disease process of women who, depending on social belonging, experience isolation in different ways, however, with several similarities in relation to gender inequalities.

The geographic breadth of the Brazilian territory and the diversity among its states reinforced the proposal and the implementation of measures to contain situations of violence against women as a result of the pandemic. The relevance of structured coping networks is also evident, since most of the strategies disclosed in the analyzed period are related to the expansion of communication channels between women and social facilities.

Telephone numbers were the most mentioned communication channels in the selected publications and, although part of them provide guidance, the narratives emphasize the act of reporting. Therefore, it is noticeable that this strategy focuses on consummated violence. The events resulting from the complaint, such as assistance with services, waiting time, processing of the judicial process and the removal of victims or offenders from the home were not identified in the selected news and comments.

A small portion of the news carried by the press and the third sector express difficulties in seeking information to report violations. This was verified in the organization of two support groups with the community, the first linked to immigrant women and the second with voluntary justice, psychology, social assistance and medical professionals.

These two strategies and strategies for disseminating information on the topic (booklets, campaigns and lives) reflect inefficiency, insufficiency and, in some cases, such as Maranhão, Roraima and Tocantins, the lack of measures by both state and federal governments to coping with the problem. Governmental actions were restricted to channels of communication with victims and remote assistance to women in situations of domestic violence.

A research carried out on measures to contain gender-based violence during the COVID-19 pandemic highlighted as international actions: information and alert campaigns such as Mask-19; reinforcement of the current aid channels and creation of complementary actions, such as the expansion of places to shelter victims (hotels and apartments); economic support from the government; meetings with women's collectives; work with offenders; contingency plan elaboration at the governmental level ${ }^{(18)}$.

In Brazil, the strategies disseminated in digital media involved measures prior to the pandemic: expanding the disclosure of the hotline, maintaining or expanding the opening hours at Brazilian Women's Houses, Reference Centers, Shelter Homes and Maria da Penha Patrol. In the Civil Police Precincts, specialized or not in assisting women, there was availability of online report registration and request for protective measures.

During the pandemic, there was an increase in complaints through Call $180^{(3)}$, indicating an increase in violations. This may be associated with a greater demand for shelter services, such as shelters or other alternative means that guarantee concrete conditions for women to escape from the situation of violence. However, in the analyzed period, there was no disclosure of strategies with this objective.

Call 180 was created in 2005 and is an important gateway to the network to combat violence against women, based on Law 11.340, of August 7, 2006, known as the Maria da Penha Law ${ }^{(19)}$. A research carried out over the eight years since the implementation of the Law revealed that the coping network has weaknesses in relation to the number of specialized services, structural and team deficiencies and in integrated care ${ }^{(20)}$.

Amidst the pandemic, it is believed that the weaknesses of the coping network have worsened, as the strategies highlighted the communication channels (telephone and cell lines, messaging applications, websites and artificial intelligence tools). Although the relevance of the communication channels is undeniable, it is worth asking: which women does this type of strategy reach? Study shows that 433 million women worldwide do not have access to the internet. In low and middle income countries, women are $10 \%$ less likely to have a cell phone and $23 \%$ less likely to use mobile internet than men $^{(21)}$.

The difficulty in reporting situations of violence during the pandemic can be seen through the $25.5 \%$ reduction in the number of police reports registered between March and April 2020, when compared to the same period in 2019 , even with the possibility of online report in part of the national territory ${ }^{(3)}$.

Although using Information and Communication Technologies (ICT) has increased globally, there is still a greater difficulty of access for women than for men. Furthermore, it is necessary to recognize the possibility of control and appropriation of these 
instruments by the offenders and the absence or limitation of telephone and internet plans for contacting the available service channels. These are some of the barriers that are imposed on the most economically vulnerable women and signal the urgency of not restricting strategies to a single modality, making it necessary to guarantee access to help in a safe manner, without greater exposure of the victims ${ }^{(22)}$.

As stated earlier, it is important to consider that confinement with their offenders, overload of domestic work, care for dependents and fear of aggression against children can be an impediment to seeking support from women. Social isolation resulted in longer contact time between family members, in a limited space. For some families, there was a restriction of subsistence sources and reduced production capacity, influencing the generation of stress due to changes in needs and basic services. Moreover, there was restriction of access to social and protective networks, and contact with family and friends ${ }^{(23)}$. A study carried out in China also highlighted the importance of social support for women in situations of violence based on messages posted in an online community, revealed as a means of support, information and encouragement for victims. Half of the shared messages (58.9\%) had social support content; of these, $22.27 \%$ involved seeking help or support from others ${ }^{(24)}$.

The pandemic highlighted the urgent need to consolidate and strengthen formal and informal support networks. With regard to the formal support network, this study did not identify strategies related to health and social assistance services. In relation to the informal support network, it was verified the importance of support from neighbors for recognition and reporting in case of perceived domestic violence

\section{Study limitations}

As limitations of this study, it is highlighted that the contents of the booklets, campaigns and lives about the theme were not analyzed, as well as the effectiveness of the strategies proposed to contain the problem. Moreover, the analyzed period does not include the entire duration of the COVID-19 pandemic; therefore, new strategies may have emerged, a fact that requires further studies of continuity analysis.

\section{Contributions to public policies}

This study contributes to the understanding of the phenomenon of violence against women during the COVID-19 pandemic, highlighting the need to improve government strategies to cope with the problem. Reporting channels and remote assistance have proved to be a possibility for the continuity of assistance to women; however, there is a need for a greater offer of reception services, as this violence mainly occurs in the domestic space. Furthermore, the study highlighted the social function of digital media to provide visibility to the phenomenon, considering the three sectors of civil society.

\section{FINAL CONSIDERATIONS}

The results of this study revealed that digital media addressed strategies associated with maintaining communication with women in situations of violence, care services and promoting information on the topic with virtual social networks. It was found that in the studied period, strategies that already existed in Brazil were adapted before the pandemic. This adaptation basically consisted of converting in-service to the remote format.

Moreover, the strategies presented in the news and comments were centered at the time of the violations, and highlighted the care provided by professionals in psychology, public security and the justice system. None of the strategies selected in the research addressed the health area, which draws attention, as the services are an important gateway for the treatment of psychological and physical problems resulting from violations.

It is believed that the COVID-19 pandemic, in addition to giving visibility to the population's health needs, also reveals the importance of investments and advances in the area of attention to violence against women, which, despite being prevalent in society, has become even more evident in this health crisis.

\section{FUNDING}

This article is the result of a project financed by the CNPq Research Productivity Scholarship, by the CAPES National Postdoctoral Program Scholarship, by FAPESP - Process 2018/07389-4 and by CNPq - Process 425350/2018-5.

\section{ACKNOWLEDGMENT}

We would like to thank the important collaboration of nurse Magnólia de Albuquerque Maranhão Vigny in the discussion meetings of the study, responsible for presenting examples of strategies to cope with violence against women adopted in French-speaking countries.

\section{REFERENCES}

1. Organization World Health (WHO). COVID-19 and violence against women: what the health sector/system can do [Internet]. Genebra: WHO; 2020 [cited 2020 May 21]. Available from: https://apps.who.int/iris/bitstream/handle/10665/331699/WHO-SRH-20.04-eng.pdf

2. Organização das Nações Unidas Mulheres Brasil (ONU Mulheres). Gênero e COVID-19 na América Latina e no Caribe: dimensões de gênero na resposta [Internet]. Brasília: ONU Mulheres; 2020 [cited 2020 Jun 03]. Available from: http://www.onumulheres.org.br/wp-content/ uploads/2020/03/ONU-MULHERES-COVID19_LAC.pdf

3. Fórum Brasileiro de Saúde Pública (FBSP). Violência doméstica durante a pandemia de Covid-19-Ed.2. São Paulo: Fórum Brasileiro de Segurança Pública [Internet]. São Paulo: FBPS; 2020 [cited 2020 Jun 03]. Available from: http://forumseguranca.org.br/wp-content/ uploads/2020/06/violencia-domestica-covid-19-ed02-v5.pdf 
4. Waiselfisz JJ. Mapa da violência 2015: homicídio de mulheres no Brasil. São Paulo; Instituto Sangari, 2015. 79 p.

5. Souto RMCV, Barufaldi LA, Nico LS, Freitas MG. Epidemiological profile of care for violence in public urgency and emergency services in Brazilian Capital, Viva 2014. Ciênc Saúde Coletiva[Internet]. 2017 [cited 2020 Sep 14];22(9):2811-23. Available from: https://www.scielo.br/ pdf/csc/v22n9/en_1413-8123-csc-22-09-2811.pdf

6. Vieira PR, Garcia LP, Maciel ELN. [The increase in domestic violence during the social isolation: what does it reveals?] Rev Bras Epidemiol. 2020;23:e200033. doi: 10.1590/1980-549720200033 Portuguese

7. Marques ES, Moraes CL, Hasselmann MH, Deslandes SF, Reichenheim ME. Violence against women, children, and adolescents during the COVID-19 pandemic: overview, contributing factors, and mitigating measures. Cad Saude Publica. 2020;36(4):e00074420. doi:10.1590/0102-311x00074420

8. Scott J. Gênero: uma categoria útil de análise histórica. Educ Real [Internet]. 1990 [cited 2020 Sep 14];5(2):5-22. Available from: https://seer. ufrgs.br/educacaoerealidade/article/view/71721/40667

9. Fonseca RMGS, Oliveira RNG, Gessner R. Violência contra as mulheres e atenção primária à saúde: um olhar de gênero. In: Kalinowski CE, organizadora. PROENF: Atenção Primária e Saúde da Família. Porto Alegre: Artmed Panamericana; 2017. p. 111-145

10. Fonseca RMGS. Gênero e saúde-doença: uma releitura do processo saúde-doença das mulheres. In: Fernandes RAQ, Narchi NZ, organizadoras. Enfermagem e Saúde da Mulher. 2 ed. Barueri: Manole; 2013. p. 32-71.

11. Egry EY, Fonseca RMGS, Oliveira MAC. Ciência, Saúde Coletiva e Enfermagem: destacando as categorias gênero e geração na episteme da práxis. Rev Bras Enferm. 2013;66(esp):119-133. doi: 10.1590/S0034-71672013000700016

12. Organization World Health (WHO). WHO announces COVID-19 outbreak a pandemic [Internet]. Genebra: WHO; 2020 [cited 2020 May 29]. Available from: http://www.euro.who.int/en/health-topics/health-emergencies/coronavirus-covid-19/news/news/2020/3/ who-announces-covid-19-outbreak-a-pandemic

13. Bardin L. Análise de Conteúdo. Lisboa: Edições 70; 2011. 280p

14. Distrito Federal (BR). Lei no 6283, de 08 de abril de 2019. Dispõe sobre a obrigatoriedade de afixação, em estabelecimentos no Distrito Federal, de avisos com o número do Disque Denúncia de Violência contra a Mulher - Disque 180. Diário Oficial do Distrito Federal [Internet]. 2019 Apr 10 [cited 2020 Jun 07]. Available from: https://www.dodf.df.gov.br/index/visualizar-arquivo/?pasta=2019|04_Abril|DODF\%20 068\%2010-04-2019|\&arquivo=DODF\%20068\%2010-04-2019\%20INTEGRA.pdf

15. Distrito Federal (BR). Lei no 6560, de 28 de abril de 2020. Dispõe sobre o protocolo de segurança no Sistema de Transporte Público Coletivo do Distrito Federal - STPC/DF voltado ao enfrentamento da violência contra a mulher. Diário Oficial do Distrito Federal [Internet]. 2020 Apr 29 [cited 2020 Jun 07]. Available from: https://www.dodf.df.gov.br/index/visualizar-arquivo/?pasta=2020|04_Abril|DODF\%20080\%20 29-04-2020|\&arquivo=DODF\%20080\%2029-04-2020\%20INTEGRA.pdf

16. Distrito Federal (BR). Lei n 6539, de 13 de abril de 2020. Dispõe sobre a comunicação dos condomínios residenciais aos órgãos de segurança pública sobre a ocorrência ou indício de violência doméstica e familiar contra mulher, criança, adolescente ou idoso em seu interior. Diário Oficial do Distrito Federal [Internet]. 2020 Apr 14 [cited 2020 Jun 07]. Available from: https://www.dodf.df.gov.br/index/ visualizar-arquivo/?pasta=2020|04_Abril|DODF\%20070\%2014-04-2020|\&arquivo=DODF\%20070\%2014-04-2020\%20INTEGRA.pdf

17. Organization World Health (WHO). World report on violence and health [Internet]. Genebra: WHO; 2002 [cited 2020 Jun 07]. Available from: http://portaldeboaspraticas.iff.fiocruz.br/wp-content/uploads/2019/04/14142032-relatorio-mundial-sobre-violencia-e-saude.pdf

18. Ruiz-Pérez I, Pastor-Moreno G. [Measures to contain gender-based violence during the COVID-19 pandemic]. Gac Sanit. 2020. doi: 10.1016/j. gaceta.2020.04.005 Spanish

19. Presidência da República (BR). Lei n 11.340, de 07 de agosto de 2006. Cria mecanismos para coibir â violência doméstica e familiar contra a mulher. Diário Oficial da União [Internet]. 2006 Aug 08 [cited 07 Jun 2020]. Available from: http://www.planalto.gov.br/ccivil_03/_ato20042006/2006/lei/111340.htm

20. Pasinato W. [Eight years of Maria da Penha Law: advances, obstacles and challenges]. Rev Estud Fem. 2015;23(2):33-545. doi: 10.1590/0104-026X2015v23n2p533 Portuguese

21. GSM Association (GSMA). Connected Women the Mobile Gender Gap Report 2019 [Internet]. London: GSMA; 2019 [cited 2020 Jun 07]. Available from: https://www.gsma.com/mobilefordevelopment/wp-content/uploads/2019/02/GSMA-The-Mobile-Gender-GapReport-2019.pdf

22. Erskine D. Not just hotlines and mobile phones: gender-based violence service provision during covid-19. New York: UNICEF [Internet]. 2020 [cited 2020 Jun 07]. Available from: https://www.unicef.org/media/68086/file/GBV\%20Service\%20Provision\%20During\%20COVID-19.pdf

23. Roesch E, Amin A, Gupta J, García-Moreno C. Violence against women during covid-19 pandemic restrictions. BMJ. 2020;369. doi: https:// doi.org/10.1136/bmj.m1712

24. Chu TH, Su Y, Kong H, Shi J, Wang X. Online social support for intimate partner violence victims in China: quantitative and automatic content analysis. Violence Against Women. 2020;1077801220911452. doi: 10.1177/1077801220911452 